\title{
Funding for roads: Understanding the South African road funding framework
}

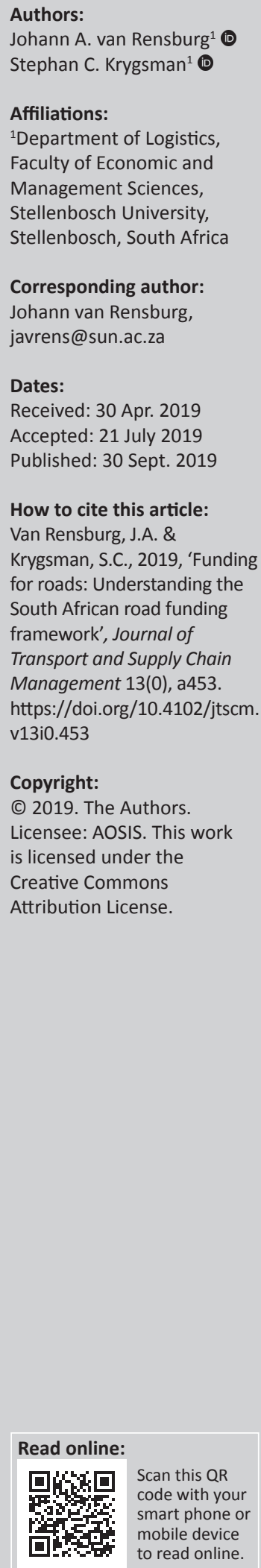

Background: A good quality road network holds numerous benefits to any country, but is dependent on sufficient and stable modes of funding and adequate financing. Funding for roads in South Africa is complex, controversial and faces different viewpoints. In this environment, it is difficult to implement any new form of road user charges, including the user-pay principle, or promote a sustainable road infrastructure policy framework.

Objectives: This article examined the road funding framework in South Africa to fully understand its capability to fund the country's road infrastructure network while quantifying and presenting the linkage between road-generated income, its distribution, allocation and the expenditure of these funds through a consolidated report and comparing the country's income and expenditure on roads to international standards.

Method: Numerous financial statements were assessed through a budget analysis to present the current road funding framework in South Africa in terms of the income generated from the road sector, its allocation, distribution and the expenditure of these funds. Local road funding trends were then compared with selected countries in terms of road-generated income, its allocation and expenditure.

Results: South Africa's current road funding framework collects a substantial amount from road users, but there is a mismatch between road-generated income collected and governmental road expenditure. Furthermore, South Africa's road expenditure in not outside the norm compared to international countries.

Conclusion: Investigation into the effectiveness of South Africa's current road cost recovery methods is needed, and the impact of future technologies on its income-generating potential must be examined.

Keywords: road-generated income; allocated income; road allocation to income ratio.

\section{Introduction and background}

Roads are undeniably important to any country as, among others, good roads can lead to an improved standard of living for the public, create more employment, provide a social service, bring about spatial agglomeration benefits and improved accessibility and support economic growth and development (Lakshmanan 2011; Terril, Emslie \& Coates 2016). Poor roads, of course, have the opposite effects (Department of Logistics 2017). However, the quality and extent of the road network are dependent on sufficient maintenance, timely upgrading and appropriate new construction of the infrastructure, which, in turn, is dependent on sufficient and stable modes of funding and adequate financing facilitated through a country's road funding framework. Funding of public infrastructure reflects who ultimately pays for the infrastructure to be built and maintained over its lifetime. Financing refers to the capital needed to pay for the investment costs up-front.

Despite the general belief in the importance of roads, funding is often controversial, faces many conflicting viewpoints and is notoriously complex. This situation is amplified in a developing country, such as South Africa, facing numerous developmental needs, limited income opportunities and a relatively small road user base. Given the nature of road infrastructure, that is, indivisible, chunky and that relies on the public good nature, financing for roads in the South African framework is nearly always under pressure. The government cannot always ensure that sufficient funds are spent on roads given other urgent developmental requirements, or that the spending on roads is done in an economically efficient manner.

South Africa has seen its fair share of public debate on how the government should fund road infrastructure and, increasingly, transport operations such as public transport. Roads, in particular, 
have received a lot of attention in the popular press, with statements ranging from alternative funding options, to increase funding demands being made by three main interest groups: the government, state-owned entities (SOE) and the public. The viewpoints are often conflicting with groups arguing for and against the fuel levy, ring-fencing the fuel levy, toll roads, arguing that motorists are unfairly taxed and that the road sector is subsidising other economic sectors. A general theme in government policy papers seems to indicate their preference for adopting the user-pay principle to fund roads.

\section{Aim and problem statement}

The aim of this article was to examine the current road funding framework in South Africa to fully understand its capability to fund the country's large road infrastructure network. This includes quantifying and presenting the linkage between road-generated income, its distribution, allocation and the expenditure of these funds through a consolidated report while comparing the country's income and expenditure on roads to international standards. According to the South African Department of Transport's Roads Infrastructure Policy Framework Draft (Department of Transport 2014), there are various policies that seek to provide for an effective, affordable and efficient road transport network. Challenges still remain, however, in many areas of the road transport sector that may impede economic development and welfare gains. These challenges include an increasing road maintenance backlog, limited funding to meet increased road network demand specifically in larger metros leading to congestion and significant civil opposition to new road cost recovery methods with specific reference to the e-toll system. Complicating the situation even further in South Africa is that the road industry, broadly defined as road users, infrastructure service providers, transport operators, government and SOE, seems saturated with distrust, suspicion and with untruths about road funding. There is no consensus in the South African road funding framework on which cost recovery methods to use, limited knowledge regarding what is collected from road users and non-users, confusion around the extent to which funds are invested in the road network and a limited knowledge base to substantiate current road user charges. Within this environment, it is very difficult to implement any new road user charges or promote a sustainable road infrastructure funding policy.

\section{Research gap}

There is a growing body of literature on road funding, both internationally and in South Africa in response, at least partly, to transport infrastructure investment demands, pricing of transport infrastructure and new technological trends that impact infrastructure demand and supply. A general review of this literature found that many studies focus on (1) the long term viability of the general fuel levy (or gas tax) in the light of technological developments such as increased fuel efficiency and electric vehicles, (2) estimating the social cost of road use to ensure economically efficient pricing or (3) considering alternative cost recovery mechanisms and approaches such as distance-based charging via GPS to accommodate both these trends (Bousquet \& Queiroz 1996; Dutzik \& Weissman 2015; Freeman 1982; Whitty \& Imholt 2007). In response to a growing public debate and public recognition of deteriorating transportation infrastructure, and the possible impact on economic performance, the United States Congress established the National Surface Transportation Infrastructure Financing Commission to embark on an investigative and analytical effort to assess the funding crisis and make recommendations to address the growing transportation infrastructure deficit (National Surface Transportation Infrasructure Financing Commission 2009). Similarly, the European Union has taken a pro-active interest in estimating marginal social costs of transport, harmonising transport tariffs and funding inter-regional transport networks (Korzhenevych et al. 2014).

Despite an active public debate internationally and in South Africa about fuel levies, toll roads and other road use taxes, very little research has been undertaken in South Africa that qualifies and quantifies transport funding, and more explicitly road funding. This study contributes to the body of knowledge by addressing this research need by providing an overview of revenue collected from road users and road expenditure in South Africa and comparing these values to international standards.

The following section presents a review of literature pertaining to the history and evolution of road funding in South Africa. Thereafter, the research methodology is presented. This is followed by research results, which explores the current type and magnitude of funding for road infrastructure in South Africa, while the section 'International road funding trends' compares local road funding trends with selected international countries. This article concludes with a discussion on how South Africa could improve its road funding policy.

\section{Literature review}

The literature review briefly discusses the evolution of the South African road funding framework from its humble beginnings to the current policy framework and proposed changes.

\section{A brief history of road funding in South Africa}

Before 1935, road construction and maintenance in South Africa was the responsibility of provincial and local authorities who funded the infrastructure through local tax income (Floor 1985). The national government was entrusted with the development of the rail system at the time to cater for freight (and to some extent passenger) transported over long distances. After 1935, the funding and financing of roads which were of national importance came to be the responsibility of national government. Funds for this activity were sourced from an import tax from every litre of fuel 
imported (3 pennies per gallon), paid into the newly established National Road Fund (Van Lingen 1960). The National Road Fund was not ring-fenced and allowed for additional state contributions.

This fuel levy had to be increased numerous times over the next 40 years to sustain the pace of road construction and maintenance. Despite these increases, the fund experienced declining income from 1974 because of a decrease in fuel use as a result of international sanctions imposed on South Africa, a rapid rise in construction costs because of inflation and high design standards (Floor 1985). The allocation of the fuel tax to the National Road Fund needed to be increased, but central government and other beneficiaries of the tax were not willing to forego any of their income for that purpose, nor was the government prepared to raise the tax on fuel because of the probable effect on the already high rate of inflation. As a result the commission began to seek other sources of income. To address these funding issues, authority to charge tolls was granted in 1983 to fund new roads, or road improvements, on stretches where an alternative route existed. The first toll road followed in June 1984 when the Tsitsikamma Toll road was opened to traffic (Floor 1985). Since 1983 the National Road Fund was also funded by a dedicated ring-fenced fuel levy in addition to tolls. This ringfencing was removed in 1988 as it was argued that earmarking reduced transparency, accountability and access to additional funds if needed in addition to the need to fund other expenditure programmes as deemed appropriate by Government (Julies 2014). Since 1988 the income from the fuel levy was allocated to the National Revenue Fund, administered by the National Treasury, which can be used for the construction and maintenance of roads, support of public transport and general government expenditure (National Treasury 2014a).

At present, the fuel levy is still South Africa's main method to collect income from road users supplemented by vehicleand user-based charges that include licence and toll fees (Van Rensburg \& Krygsman 2019). These taxes and tolls accrue to the National Treasury and road-based SOE's, except the Road Accident Fund (RAF) levy which is ring-fenced. Treasury subsequently allocates the general revenue to provinces, municipalities and SOE's based on input from the National Department of Transport (NDoT) on whose signals National Treasury responds. The magnitude of the fuel levies, and other charges, is not the result of exact road user cost calculation but is mainly the outcome of the fiscal policy of government, which, in turn, is determined by the revenue requirements for infrastructure, social policy, the need to attract investment, the tax burden, among others.

With the possible exception of the National Transport Master Plan (NATMAP) (Department of Transport 2013), none of the South Africa road policy documents including the White Paper on Transport Policy, the National Land Transport Strategic Framework (NLTSF) and the National Development Plan (NDP) is very specific on how to fund road infrastructure
(Department of Transport 2013; National Planning Commission 2009; Republic of South Africa 2015b). The overall idea seems to be that the user of the road, or infrastructure, should pay for their use based on the user-pay principle. There is, however, very little evidence, indicating how much users should pay, how they should pay or which changes in the institutional regime will be required to facilitate the user-pay principle.

\section{The changing South African policy framework}

Overall South African transport policy documents emphasise that the transport sector, specifically the road sector, is experiencing funding problems. For example, the Draft White Paper on Roads Policy for South Africa (2018) emphasise the shortage of funds for roads and maintenance in particular, leading to a significant backlog in maintenance. The Policy mentions a current road maintenance backlog of R197 billion (Department of Transport 2018a) and proposes that the Department of Transport and National Treasury explores the full range of funding mechanisms available to enable increased funding. These include the fuel levy, vehicle licence fees, partnering with the private sector, seeking income opportunities from existing assets and potentially other innovative funding sources. The adoption of the user-pay principle is mooted, although the principle is not really elaborated on. A Toll Regulator is proposed by the policy, as part of the Transport Economic Regulator with the aim of creating an environment of coherence, independence, accountability, transparency, predictability and capacity in the development and approval of annual toll tariffs. Finally, the Policy states that government will not make additional funding available for the road sector and that more efficient expenditure in the road sector is needed. To this end, the Policy states that road authorities will improve efficiencies in budget expenditure in the road sector by adhering to a 'minimum level of service' to be achieved and that a performance-based approach be implemented to administer grant funds.

The Economic Regulation of Transport Bill, published for comments in 2018, aims to 'consolidate the economic regulation of transport within a single framework and policy, to establish the Transport Economic Regulator, to establish the Transport Economic Council' to, importantly, administer price regulation in the transport sector (Department of Transport 2018b). An Independent Strategic Transport Economic Regulator will, as one of the functions, implement price controls and regulate tariffs for transport facilities and services based on fair and equitable pricing principles. The Bill acknowledges that South Africa has important economic infrastructure, including roads, rail, ports and airports, and that this infrastructure should be funded to stimulate the economy. The Bill states that the proposed price controls for a regulated entity may comprise a schedule of tariffs, charges, fees, tolls or other amounts that may be imposed by the regulated entity for the use of, or access to, any transport service, or facility offered by the 
regulated entity. While tolls and road user charges, such as heavy goods vehicle charges, will be subject to price regulation, the fuel levy, or taxes imposed by the Treasury, will fall outside in the jurisdiction of the proposed Regulator.

Lastly, the Draft Revised White Paper on National Transport Policy (2017) advocates to foster a sound financial base for transportation infrastructure through appropriate funding sources (Department of Transport 2017). This policy document refers to the various types of infrastructure and how these differ in their suitability and economic viability for cost recovery through user charging and/or direct recovery of investments by the private sector. Distinction is made between infrastructure for social access, requiring government funding or subsidy and infrastructure suitable for indirect user charging such as fuel levies, license fees, tax on fares (however not reflecting on the long term viability of the various charging mechanisms) and finally infrastructure suitable for private sector investment and partnerships involving both public and private sector investments, for example, toll roads. The White Paper propose that transport investments should be justified in terms of quantum and focus area by research and data evaluation. This will ensure that investment is directed to those transport infrastructure projects with a higher likelihood of supporting economic development.

\section{Research methodology}

For this study, a budget analysis was performed to determine how and to what magnitude the South African government source income from road users, how this income is managed and ultimately spent. The study also compared local road funding trends with selected countries, in terms of three ratios, for example, road expenditure to income ratio, a road expenditure to gross domestic product (GDP) ratio and road expenditure to allocated road expenditure ratio (Gomez \& Vassallo 2014). The research methodology provides a description of the methods undertaken.

\section{Description of methods undertaken}

For the budget analysis, numerous government acts, bills and policy framework documents were, assessed to determine which spheres of government are mandated with the responsibility to finance and provide road infrastructure and road-related operation and regulation activities in South Africa (Department of Transport 2011, 2013; National Planning Commission 2009; Republic of South Africa 1996, 2000, 2009, 2012, 2015a, 2015b; Transport for Cape Town 2013). This process identified the national government, which included National Treasury and the NDoT; provincial government, which included all nine provinces in South Africa; local government, which included eight metropolitan cities, 44 district municipalities and 226 local municipalities across South Africa, and lastly six state-owned entities, which include the South African National Road Agency (SANRAL), the RAF, the Cross Border Road Transport Agency, the
Driving Licence Card Account, the Road Traffic Infringement Agency and the Road Traffic Management Corporation as role-players who either collect, are allocated revenue or who is responsible for road expenditure, be that for road construction, maintenance, upgrade or road-related operation and regulation activities.

All the road cost recovery methods, which are used by all road-related entities in South Africa to collect income from road users, were determined based on research by Stander and Pienaar (2000). Each income source was then categorised by identifying the sphere of government or road-related SOE that is responsible for this income source. This process identified 14 income sources, that is, the fuel levy, the RAF levy, DSML levy, pipeline levy, IP marker levy, custom and excise levy, fines/fees and permits, licences fees, toll fees from SANRAL and its concessions, $\mathrm{CO}_{2}$ emissions levy, tyre levy, value-added tax (VAT) on vehicle sales, import duties on vehicles and VAT on vehicle parts.

In 2015, a review of each entitie's publicly available financial statements and budget reports were undertaken to account for all road-generated income collected. This was followed by tracing all road-generated income by means of the various financial statements to the point where it was spent on road construction, maintenance, upgrade or road-related operation and regulation activities. The expenditure was further divided into expenditure that was allocated or ring-fenced for specific expenditure programmes, expenditure on all road infrastructure programmes and expenditure on road operation and regulation activities.

Following the assessment of the consolidated financial records, local road funding trends were then compared through a comparative analysis with selected countries, which included the United States, France, Spain, the United Kingdom, Germany and Switzerland, in terms of a road expenditure to road income ratio, a road expenditure to GDP ratio and road expenditure to allocated road expenditure ratio, based on the methodology by Gomez and Vassallo (2014). The ratios were calculated by dividing the total road expenditure by the total income collected in the road sector, dividing the road expenditure by the country's GDP value and dividing the road expenditure that is allocated for specific purposes by the total income collected in the road sector for each year.

\section{Ethical considerations}

The research in this article is part of J.A.v.R.'s doctoral study on distance-based road user charges. Ethical clearance was obtained in 2018 under project number 7188 from the Research Ethics Committee: Human Research (Humanities) of Stellenbosch University.

\section{Research results}

The results section, firstly, provides an overview of the South African road infrastructure network, after which an account is given of the collection of revenue from road users, the 
allocation of these funds, the expenditure of funds on the road network, the fund distribution process and finally the comparison of South Africa's road funding trends with international countries.

\section{The South African road network}

South Africa boasts the 10th largest road network and 18th largest paved road network in the world (Kannemeyer 2013). The country has an estimated road network length of 750000 $\mathrm{km}$ (2015), which consists of $158124 \mathrm{~km}$ of paved roads and $591876 \mathrm{~km}$ of gravel roads (Department of Transport 2016). The SANRAL is responsible for $2.85 \%$ of the network (SANRAL 2015). Of the remainder, $36.48 \%$ of the network falls under the jurisdiction of provinces, $8.82 \%$ under metropolitan regimes, $34.26 \%$ under the jurisdiction of municipalities and $17.59 \%$ of all roads are not proclaimed. The value of the road network was estimated at between R1.2 and R2 trillion in 2014 (National Treasury 2015).

While scientific evidence is scant, SANRAL has argued that the portion of the national road network that was older than its original 20-year design life has grown from $36 \%$ to $78 \%$ in 2008 and that the current road maintenance backlog is estimated at R197bn (Kannemeyer 2011, 2014). The condition of the South African road network varies between transport authority and type of road. Overall, $30 \%$ of the network was in poor to very poor condition in $2008,30 \%$ in fair condition and $40 \%$ in good to very good condition.

According to eNatis, there were 10.35 million self-propelled vehicles using the country's roads network in 2014 (eNatis 2015b). This translates into 191 vehicles per 1000 members of the population. From the available statistics, the annual growth in the vehicle population is estimated at around $4 \%$. In terms of vehicles per capita, South Africa ranks 85th in the world. Consequently, the extensive road network is only serviced by a relatively small vehicle population, which will have an implication on the user's cost responsibility. This mismatch between network size, representing the supply and number of vehicles, representing the demand, implies that the funding requirement and resulting allocation to roads (upgrading, maintenance or expansion) will be proportionally more when compared to countries with a more even balance of road users and road network.

\section{Collection of funds from road users}

Road users in South Africa pay various taxes, charges and fees as a result of owning and operating a vehicle. In 2014, R166.4bn was collected from road users and vehicle owners (Table 1). This can be divided into direct income that refers to income that is the result of the actual use of the network and includes the fuel levy. This income is influenced by the vehicle fleet (size of the vehicle fleet) and road use (kilometres of travel). Indirect income sources, are general taxes related to vehicle ownership and vehicle sales (number of vehicles sold and imported). There is no relationship between road use and indirect income sources. Total direct income, also termed road-generated revenue, was R99.9bn in 2014. The biggest contributors were the fuel levies consisting of the general fuel levy, RAF levy, DSLM, pipeline levy and tracer dye levy which contributed about $30 \%$ to the price per litre of fuel in 2014.

TABLE 1: Road-generated income ('000).

\begin{tabular}{|c|c|c|c|c|c|c|c|}
\hline Income sources & 2010 & 2011 & 2012 & 2013 & 2014 & $\%$ & Collected by \\
\hline Fuel levy & R34 417577.00 & R36 602263.00 & R40 410389.00 & R43 300000.00 & R47 516564.00 & 29 & National \\
\hline Road accident fund & R14 474058.00 & R16 989071.00 & R17 380217.00 & R20 352981.00 & R22 457948.00 & 13 & SOE \\
\hline Fines/fees and permits & R9 011537.00 & R10 988624.00 & R12 933722.00 & R10 853033.00 & R10 678864.00 & 6 & Provincial \\
\hline License fees & R5 057977.00 & R5 953006.00 & R6 530434.00 & R6 765016.00 & R7 349077.00 & 4 & SOE and local \\
\hline Toll fees: concessions $†$ & R3 987937.00 & R4 605700.00 & R5 029190.00 & R5 420129.00 & R5 846819.00 & 3 & SOE \\
\hline Toll fees: SANRAL & R2 073060.00 & R1 987379.00 & R2 199090.00 & R2 759839.00 & R4 221433.00 & 3 & SOE \\
\hline $\mathrm{CO}_{2}$ emissions & R625 891.00 & R1 617353.00 & R1 567382.00 & R1 636848.00 & R1 684160.00 & 1 & National \\
\hline DSML & R51 000.00 & R53 000.00 & R152 000.00 & R140 000.00 & R170 000.00 & $<1$ & National \\
\hline Pipeline levy & R31 000.00 & R32 000.00 & R33 000.00 & R35 000.00 & R37 000.00 & $<1$ & National \\
\hline IP marker levy & R1000.00 & R1000.00 & R1000.00 & R1000.00 & R1000.00 & $<1$ & National \\
\hline VAT on vehicle sales & R28 197380.00 & R31 099740.00 & R34 993000.00 & R37 154040.00 & R37 893660.00 & 23 & National \\
\hline Import duties: vehicle & R10 442000.00 & R14 348000.00 & R18 702000.00 & R21 635000.00 & R22 567000.00 & 3 & National \\
\hline VAT on vehicle parts & R3 909640.00 & R4 126080.00 & R4 496380.00 & R4 788700.00 & R5 009760.00 & 14 & National \\
\hline Custom and excise levy & R817 000.00 & R847 000.00 & R875 000.00 & R922 000.00 & R981 000.00 & $<1$ & National \\
\hline Total income & R113 097057.00 & R129 250216.00 & R145 302804.00 & R155 763586.00 & R166 414285.00 & 100 & - \\
\hline Direct income & R69 731037.00 & R78 829396.00 & R86 236424.00 & R91 263846.00 & R99 962865.00 & 60 & - \\
\hline Indirect income & R43 366020.00 & R50 420820.00 & R59 066380.00 & R64 499740.00 & R66 451420.00 & 40 & - \\
\hline
\end{tabular}

Source: Arrivealive, 2016, 2003 Traffic offence survey: Comprehensive report on fatal crash statistics and road traffic information, viewed 30 November 2016, from https://www.arrivealive.co. za/2003-TRAFFIC-OFFENCE-SURVEY-Comprehensive-Report-on-Fatal-Crash-Statistics-and-Road-Traffic-Information-11; Bakwena, 2016, Toll tariffs, viewed 01 June 2016, from https://www. bakwena.co.za/toll-tariffs/; Department of Energy, 2013, Fuel price margins, viewed 02 June 2016, from http://www.energy.gov.za/files/esources/petroleum/petroleum_fuelprices.html; International Transport Forum, 2015, Transport infrastructure investment and maintenance spending, OECD, viewed 25 August 2016, from https://stats.oecd.org/Index.aspx?DataSetCode=ITF_INVMTN_DATA; National National Treasury, 2014b, National budget, National Treasury, Pretoria, South Africa; National Treasury, 2014c, National budget income 2014, National Treasury, Pretoria, South Africa; National Treasury, 2014d, Provincial budget, National Treasury, Pretoria, South Africa; National Treasury, 2015, Provincial budgets and expenditure review 2010/11 - 2016/17, South Africa, National Treasury, Pretoria, South Africa; N3TC, 2016, Toll tariffs, viewed 01 June 2016, from http://www.n3tc.co.za/toll-tariffs/; Road Accident Fund, 2014, RAF annual report 2014, Road Accident Fund, Pretoria, South Africa; SANRAL, 2016, Toll tariffs, viewed 01 June 2016, from https://www.nra.co.za/live/content.php?Item_ID=202; SAPIA, 2014, SAPIA annual report 2014, SAPIA, NOVA Communications, Pretoria, South Africa; Statistics South Africa, 2014, Statistical release motor trade sales. Pretoria, StatsSa, Pretoria, South Africa; Statistics South Africa, 2016, Gros domestic product first quarter 2016, StatsSa, Pretoria, South Africa; Trans African Concession, 2016, Toll tariffs, viewed 01 June 2016, from http://www.tracn4.co.za/toll-plazas-toll-fees/.

SANRAL, South African National Road Agency; $\mathrm{CO}_{2}$, carbon dioxide; DSML, demand side management levy; IP, illuminating paraffin; VAT, value-added tax; SOE, state-owned entities.

$\dagger$, This is an estimate based on Annual Average Daily Traffic and tariff.

$\$$, Other income sources from road users include: (1) developer contributions, (2) parking fees and permits, and (3) tyre tax (R500 000000 in 2015). 
The national government collects $31 \%$ of the direct income, provincial government $6 \%$, SOE $19 \%$ and local governments collected $4 \%$, as illustrated in the last column of Table 1 . Total direct income grew by 43\% between the period 2010 to 2014 . The fuel levy, RAF, license fees collected and toll fees by SANRAL and its concessions grew by $38 \%, 55 \% 45 \%, 104 \%$ and $47 \%$, respectively. Over the same period the vehicle population in South Africa grew by $17 \%$, while the average annual inflation rate was only $7 \%$ during this period (eNatis 2015; Road Traffic Management Corporation 2014).

\section{Allocation of funds to roads}

Funds from the road-generated income and other government sources can be earmarked for road construction and maintenance projects. This is known as allocated income, which is defined as the annual income that is dedicated to funding roads, without taking into account whether or not it is dedicated to specific road projects (Gomez \& Vassallo 2014). Allocated income in South Africa is distributed in the form of road infrastructure and maintenance grants to various transport authorities (Table 2). Allocated grants include the Public Transport Infrastructure Grant, the Provincial Maintenance Grant, the Infrastructure Overload Control Grant and the SANRAL's non-toll network, Coal Haulage network grant and Gauteng Freeway Improvement Project Grant. In 2014, South Africa allocated R32.5bn towards the construction and maintenance of roads. The majority of this allocation, $\pm 70 \%$, came from the national government and was distributed to SANRAL, the provinces and metropolitan areas. It, then, is the responsibility of the SOE and other spheres of government to use the funds for the purpose it was intended.
The largest share of the allocated income was for the Provincial Roads Maintenance Grant and SANRAL's non-toll network, which consist of over $273000 \mathrm{~km}$ and $18000 \mathrm{~km}$, respectively. Allocated income increased by $121.5 \%$ over the period 2010-2014.

\section{Expenditure of funds on roads}

Annual expenditure on roads by all spheres of government and SOE includes infrastructure investment and maintenance grants (Table 3). During 2014, R49.2bn was spent on road maintenance, upgrades and new construction. This amount includes the allocated income. Road expenditure increased by $14.2 \%$ over the period $2010-2014$ or on average $3.5 \%$ per year.

\section{The distribution process of funds}

For the 2014-2015 financial year, the South African Revenue Services (SARS) collected R49.4bn from road users with the local and provincial governments and SOE collecting the remaining $\mathrm{R} 50.5 \mathrm{bn}$ to account for the $\mathrm{R} 99.9 \mathrm{bn}$, as shown in Table 1 . This $\mathrm{R} 49.4 \mathrm{bn}$ represents roughly $5 \%$ of the national government's total tax revenue for 2014 (National Treasury 2014c). The NDoT received a transfer of $\mathrm{R} 48.7 \mathrm{bn}$ from the treasury or roughly $50 \%$ of what was collected from the road users (2014). Of this amount, the NDoT transferred R32.3bn to the SOE, provincial and municipal governments for road infrastructure and road sector operational activities. This includes conditional grants to the provincial government (R14.1bn) and the municipal government (R5.9bn) and SOE (R12.3bn) to be used for road infrastructure and road operations activities. The remaining R17.1bn was allocated by the NDoT to other

TABLE 2: Allocated income ('000).

\begin{tabular}{|c|c|c|c|c|c|}
\hline Grants and toll income & 2010 & 2011 & 2012 & 2013 & 2014 \\
\hline Toll fees: SANRAL & R2 073060.00 & R1 987379.00 & R2 199090.00 & R2 759839.00 & R4 221433.00 \\
\hline Toll fees: concessions & R3 987937.00 & R4 605700.00 & R5 029190.00 & R5 420129.00 & R5 846819.00 \\
\hline SANRAL: non-toll & R4 065177.00 & R5 262566.00 & R5 934636.00 & R6 394541.00 & R7 515300.00 \\
\hline SANRAL: Coal Haulage & - & R464 782.00 & R667 959.00 & R648 910.00 & R665 498.00 \\
\hline SANRAL: Gauteng Freeway Improvement Project & - & R5 750000.00 & - & - & - \\
\hline Overload control & R5390.00 & - & - & - & - \\
\hline Provincial road maintenance & R4 862460.00 & R6 389635.00 & R8 988337.00 & R8 696210.00 & R9 361498.00 \\
\hline Public transport infrastructure & R3 699462.00 & R4 988103.00 & R4 803347.00 & R4 668676.00 & R4 968029.00 \\
\hline Total & R18 693486.00 & R29 448165.00 & R27 622559.00 & R28 588305.00 & R32 578577.00 \\
\hline
\end{tabular}

Source: National Treasury, 2014b, National budget, National Treasury, Pretoria, South Africa; SANRAL, 2015, The South African National Roads Agency Annual Report 2015, SANRAL, Pretoria, South Africa.

SANRAL, South African National Road Agency.

TABLE 3: Road expenditure ('000).

\begin{tabular}{|c|c|c|c|c|c|}
\hline Transport entities & 2010 & 2011 & 2012 & 2013 & 2014 \\
\hline National government & - & - & - & - & - \\
\hline Provincial government & R14 269254.00 & R15 993253.00 & R17 634059.00 & R18 571254.00 & R20 169802.00 \\
\hline Municipalities & R9 893480.00 & R12 260308.00 & R12 181889.00 & R13 564588.00 & R14 507056.00 \\
\hline SOE & R18 972179.00 & R15 852104.00 & R15 191965.00 & R15 253520.00 & R14 584260.00 \\
\hline SANRAL & R13 523456.00 & R12 638823.00 & R12 881594.00 & R13 079213.00 & R12 850991.00 \\
\hline SANRAL: concessions & R5 448723.00 & R3 213281.00 & R2 310371.00 & R2 174307.00 & R1 733269.00 \\
\hline Total & R43 134913.00 & R44 105665.00 & R45 007913.00 & R47 389362.00 & R49 261118.00 \\
\hline
\end{tabular}

Source: Authors' own calculations; National Treasury, 2014b, National budget, National Treasury, Pretoria, South Africa; SANRAL, 2015, The South African National Roads Agency Annual Report 2015, SANRAL, Pretoria, South Africa.

SANRAL, South African National Road Agency; SOE, state-owned entities. 
programmes, including rail and maritime transport, civil aviation, administration, and so on.

The RAF collected levies of R22.4bn (in 2014) from road users in the form of a levy raised on fuel. As with other taxes, the RAF levy is paid to SARS, who transferred it to the RAF in accordance with provisions of the Customs and Excise Act, 1964 (Act No. 91 of 1964) and the Road Accident Fund Act (56 of 1996).

State-owned entities and provincial and municipal governments may also use their own income to fund road operation activities and infrastructure investment. The own income includes tolls (R10bn) in the case of SANRAL and the toll concessionaires and local licensing fees, parking and permit charges, developer contributions (R18bn) and so on in the case of provincial and municipal governments. Furthermore, the provincial and municipal governments may also access loans, government grants and their equitable revenue share or own receipts from non-transport-related activities (such as property tax) to fund transport infrastructure and operations.

For the 2014-2015 financial year, R119.5bn was spent on road network infrastructure, transport operations and regulation in South Africa. Of this amount, only R49.2bn (Table 3) was spent on road infrastructure, while the remaining R70.2bn (Figure 1) was spent on road transport-related operations and regulation which included public transport subsidies. The South African National Road Agency and the provincial and municipal governments were responsible for the road infrastructure investment. All spheres of government and all of the SOEs (SANRAL, Road Accident Fund, Cross Border Road Traffic Agency, Driving Licence Card Account, Road Traffic Infringement Agency and Road Traffic Management Corporation) contributed to the operational and regulation expenditure of R70.2bn.

In summary, during 2014-2015, R99.9bn was collected through various charges, levies and taxes by all levels of government. A simple calculation reveals that assuming a vehicle fleet of 10350835 travelling a distance of $162405499396 \mathrm{~km}$, an average hypothetical vehicle contributed R0.62 per vehicle kilometre to the public treasury (Department of Transport 2016; SANRAL 2015). R49.2bn was spent on road infrastructure (planning and design for road upgrade, maintenance and new construction) by SANRAL, and provincial and municipal governments. All authorities spent R70.2bn on road operations and regulation resulting in R119.5bn being spent on road infrastructure, regulation and operations. This resulted in an investment of R0.74 per vehicle kilometre.

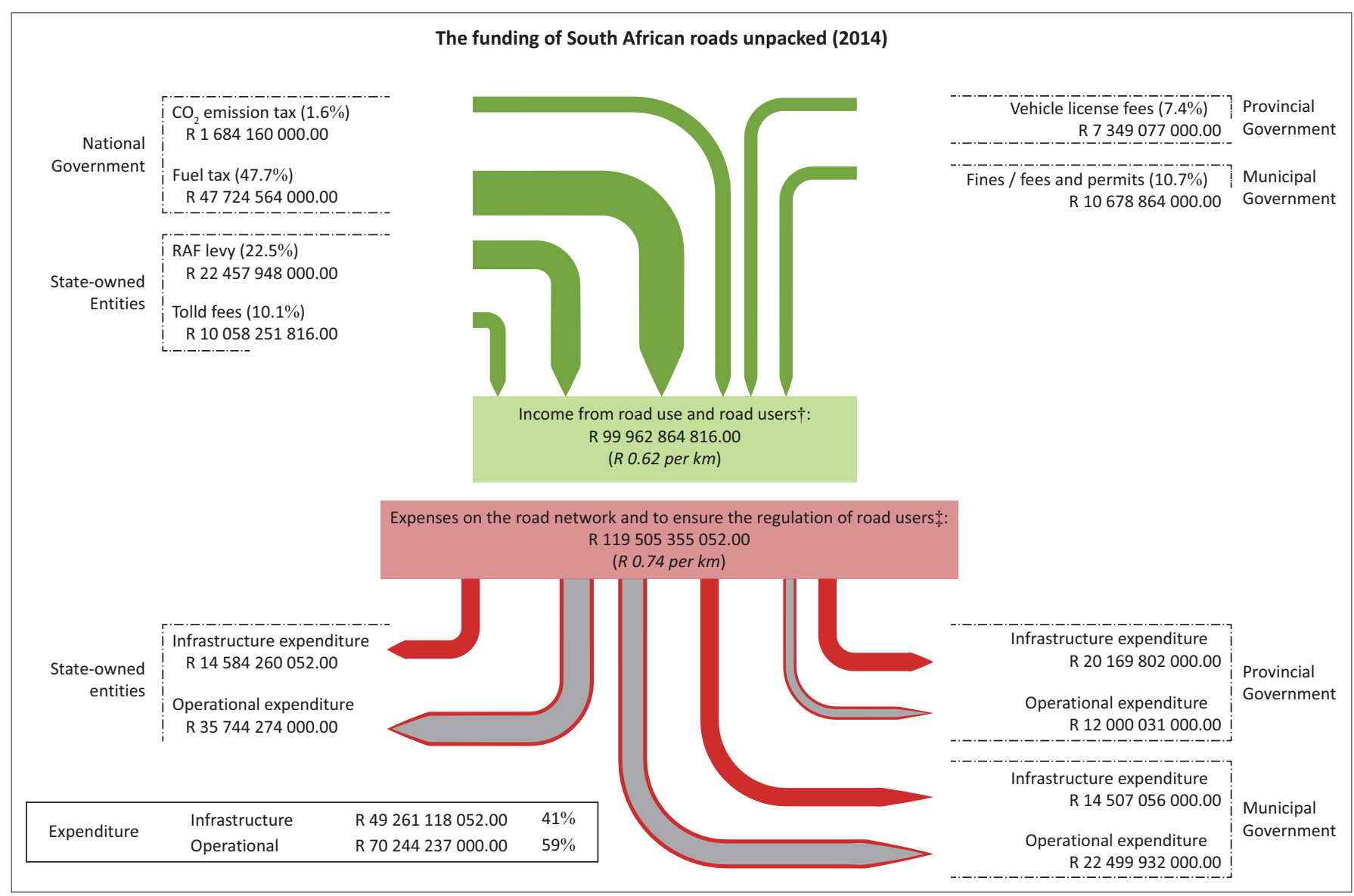

$\mathrm{CO}_{2}$, carbon dioxide.

$\dagger$, Income collected on $746835 \mathrm{kms}$ of roads by a vechicle fleet of 10350835 travelling a distance of $162405499396 \mathrm{kms}$ in 2014.

$\sharp, R 0.30$ spent on the road infrastructure per vechicle $\mathrm{km} ; \mathrm{R} 0.44$ spent on the road operations per vechicle $\mathrm{km}$.

FIGURE 1: The funding of roads in South Africa (2014). 


\section{International road funding trends}

Despite the active road funding debate, it is unclear whether South Africa spends comparatively more or less on its road network than its peers. Even with the values stated in the previous section, it is not known how South Africa compares to them. To put road funding into perspective, the country's road funding framework is compared to selected international examples. The South African road funding model was compared with other countries, by calculating three ratios, that is, the road expenditure to income ratio, the road expenditure to GDP ratio and the road allocation to income ratio.

The road expenditure to income ratio shows the money spent on roads (construction and maintenance) for every South African Rand charged for road use. It is obtained by dividing road expenditure by road-generated income. Figure 2 shows the road expenditure to income ratio for selected developed countries (Europe and the United States) during the period 2004-2009 (Gomez \& Vassallo 2014) and for South Africa during the period 2011-2015. While the periods may not coincide, because of the unavailability of data, the general trend can still be observed.

Three groups of countries can be distinguished: firstly, nations with a high commitment of road income (more than $60 \%$ ) to road purposes that includes America and Switzerland. Secondly, with an average expenditure rate of road income (between $40 \%$ and 50\%) that includes France, Spain and South Africa. Thirdly, countries with low levels of expenditure (30\% or below) that includes Germany and the United Kingdom. The third group still spends much on roads, but their taxes for road use is also very high (Van Rensburg \& Krygsman 2015). What is apparent from Figure 1 is that all these countries' road-generated income exceeds the income expenditure (the ratio is $<1$ ) with the exception of the United States. The United States has a ringfenced highway fund into which all road-generated income is allocated. The Highway Trust Fund has been frequently under severe fiscal pressures and requires frequent federal bailouts. The United States fuel taxes are the lowest in the world and the United Kingdom and Germany have some of the highest fuel taxes (Metschies 2013).

The second ratio, the road expenditure to GDP, shows the amount of money spent on road construction and maintenance for every South African Rand the country generates through the production of goods and services or our GDP. The GDP measures the value of economic activity within a country. Strictly defined, GDP is the sum of the market values, or prices, of all final goods and services produced in an economy during a period of time. What is immediately apparent from Figure 3 is that South Africa, on average, spent a greater amount $(1.2 \%-1.6 \%)$ of its GDP over the period 2011-2015 on road construction and maintenance than the selected developed countries $(0.1 \%-1.4 \%)$ over the period 2004-2009. Numerous other OECD countries were included to compare South Africa over the period 2011-2015, showing the same finding of high GDP spending on road expenditure. Gomez and Vassallo (2014) states that this ratio is not necessarily comparable because it can vary with population, area or density of population. While the other countries in Figure 3 are all developed countries, the higher ratio may be reflective of South Africa's commitment to an infrastructure-led growth policy and investment in economic infrastructure. South Africa, however, does seem to allocate a reasonable share of its GDP to roads, but this share is steadily declining as other sectors of the economy receive greater political attention. The international average in 2014 was $0.67 \%$ of GDP spent, with South Africa at $1.29 \%$ (OECD 2014).

The road allocation to income ratio shows the share of roadgenerated income earmarked for road construction and maintenance projects (Figure 4). The United States has the highest road allocation ratio as it earmarks federal and state taxes for road construction and maintenance projects. Switzerland mainly allocates vignette, fuel tax and heavy vehicle fees for this purpose. South Africa allocates between 0.3 and 0.4 of every rand collected to road infrastructure and maintenance. No single road-generated income method,

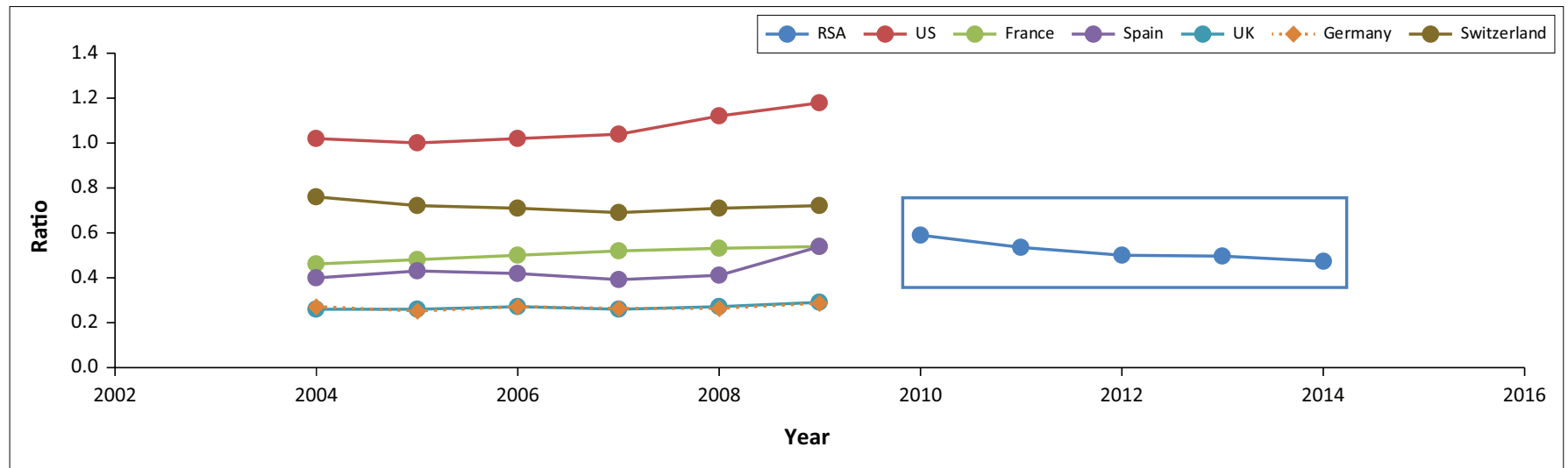

Source: Authors' own calculations; Gomez, J. \& Vassallo, J., 2014, 'Comparative analysis of road financing approaches in Europe and the United States', Journal of Infrastructure Systems 20(3), 1-8. https://doi.org/10.1061/(ASCE)IS.1943-555X.0000193.

RSA, Republic of South Africa; US, United States; UK, United Kingdom.

FIGURE 2: Expenditure to income ratio for selected countries. 


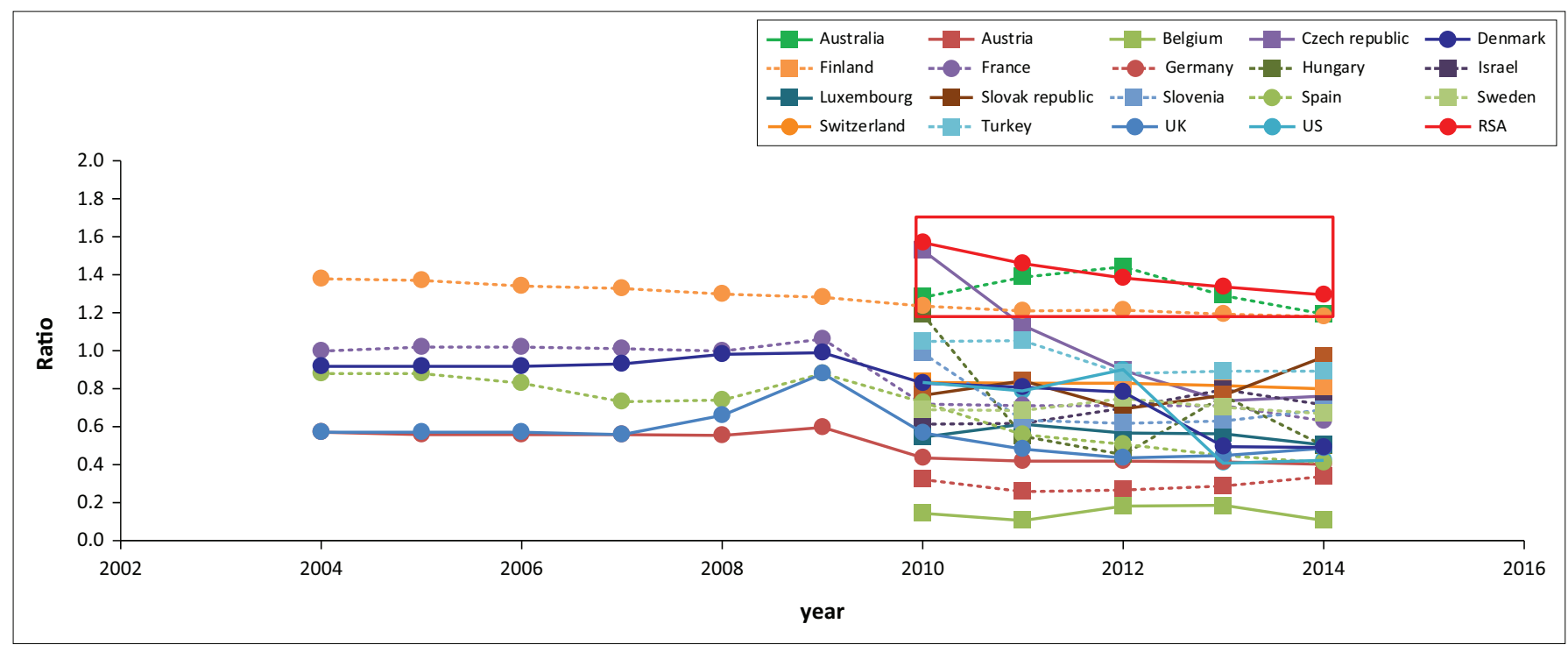

Source: Authors' own calculations; Gomez, J. \& Vassallo, J., 2014, 'Comparative analysis of road financing approaches in Europe and the United States', Journal of Infrastructure Systems 20(3), 1-8. https://doi.org/10.1061/(ASCE)IS.1943-555X.0000193.

UK, United Kingdom; US, United States; RSA, Republic of South Africa.

FIGURE 3: Road expenditure to gross domestic product ratio for selected countries.

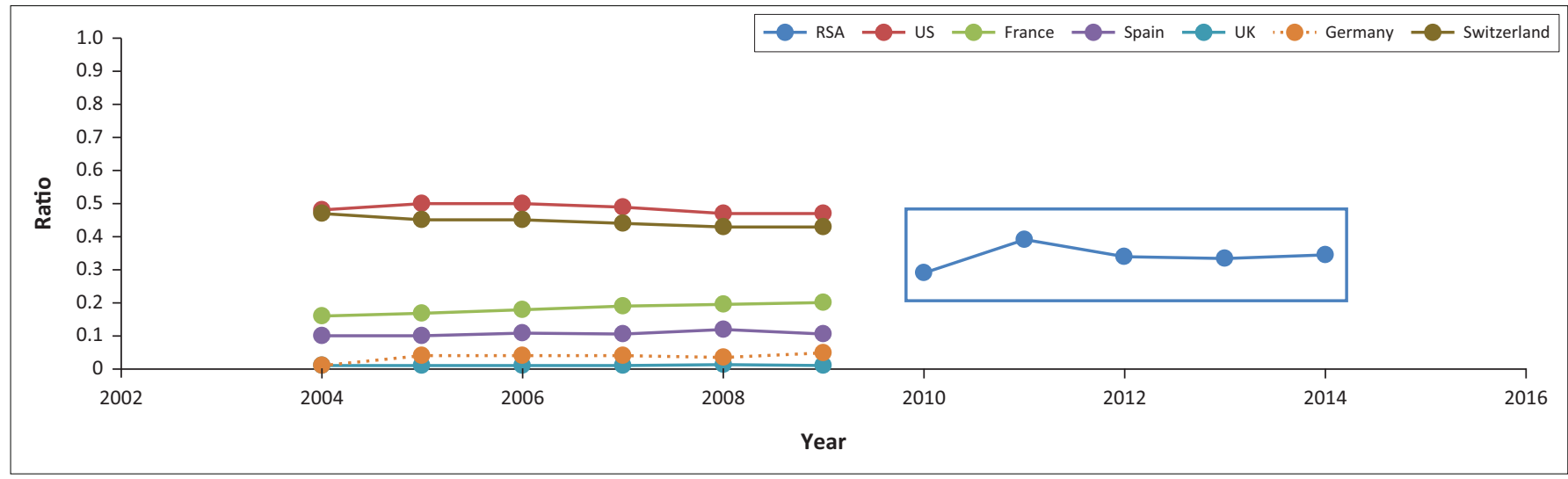

Source: Authors' own calculations; Gomez, J. \& Vassallo, J., 2014, 'Comparative analysis of road financing approaches in Europe and the United States', Journal of Infrastructure Systems 20(3), 1-8. https://doi.org/10.1061/(ASCE)IS.1943-555X.0000193.

RSA, Republic of South Africa; US, United States; UK, United Kingdom.

FIGURE 4: Road allocation to income ratio for selected countries.

except toll fees, is allocated directly for road construction and maintenance in South Africa. Although the periods of analysis do not overlap and this does not lend itself to direct analysis, this does not invalidate the findings.

\section{Conclusions and findings}

Roads support economic development and satisfy most of the government's social and development objectives. A clear case can therefore be made to fund roads and ensure a sufficient and reliable income source. The question is therefore how much funding should be allocated to roads and how to secure income from road users.

The literature gives the impression that South Africa does not have a specific, structured and extensive road policy yet. The magnitude of funding required for the road sector is relatively unknown; the amounts stated or projects proposed by the road industry role-players are not necessarily economically justified and the share of costs that road users should pay for funding South Africa's road infrastructure is unknown. Current policy documents extensively advocate for the userpay principle, but this principle in terms of price setting for public infrastructure has a specific meaning or rather purpose and does not guarantee that sufficient levels of funding are achieved. It is rather difficult to determine if road users currently pay too much or less than what is required of them, but it is known that the current price of our fuel levy which is ultimately paid by the road users is not sporadically too high or low compared to international countries given our large road infrastructure network. Furthermore, current policy documents do not regulate road tariffs, and although there is a move to establish an economic transport regulator, it will not necessarily look at road taxation. This seems to be based more on a fiscal decision to collect income for the national fiscus and that economically efficient road taxes based on the user-pay principle are not taken into consideration. These policy documents also do not quantitatively show the actual need for funding. 
This article illustrated that there are various revenue sources of different magnitudes in South Africa's road funding framework of which the fuel levy only contributd $29 \%$ in 2014. Accordingly South Africa collects quite a lot from road users through actual road use and from owning a vehicle, but this is less than what is invested in the road sector each year. A lot of funding seems to be diverted from the purpose of administration and regulation in the road sector and as such only about $40 \%$ of the income collected gets invested in actual road infrastructure. Compared to selected developed countries in terms of how much income South Africa generates and spends on road infrastructure as a percentage of GDP, it is definitely not under the norm. The problem may be structural as South Africa has a big road network and a very small vehicle fleet, where too many roads were built and historically road funding was not done economically. It, however, seems that national governments are actively allocating (spending) more on road infrastructure each year compared to provincial and municipal governments that are not increasing road infrastructure spending at a stable level out of their income account but rather at a marginal level because of the prioritisation of other expenditure programmes.

South Africa needs a comprehensive, detailed policy drawn up by independent and verifiable research that indicates how much we should pay to maintain the infrastructure that is important for economic development. It must be acknowledged that roads compete with other infrastructure and social activities and that total cost will not always be covered given our large road infrastructure and small user base. Thus, hard decisions will have to be taken. An economic regulator is indeed needed to set prices at the correct level and to win the confidence of the public, which is not the case in the current setting. To improve South Africa's road funding policy, data and performance measures are needed. The assessment of current cost recovery methods is also needed, investigating the effectiveness thereof and the impact of future technologies on its income-generating potential. It is important to strive for fair and efficient road user charges that adhere to the user-pay principle, whose meaning is not clearly defined and calculation thereof non-existent. The framework should not be oblivious of new cost recovery techniques that are made possible through innovation in technology, and that may possibly replace current income sources such as distance-based road user charges through location-aware technologies that may be more suited to adapt the user-pay principle. It may be time for tariffs to be differentiated based on external cost that shows the need for congestion pricing to be implemented in South Africa.

\section{Acknowledgements Competing interests}

The authors declare that they have no financial or personal relationships that may have inappropriately influenced them in writing this article.

\section{Authors' contributions}

S.C.K. is the project leader and is the promoter for J.A.v.R.'s doctoral study, who was primarily responsible for the research. Both authors contributed to the writing of the article.

\section{Funding information}

The research presented in this article was partly funded by the Southern African Bitumen Association (SABITA) and the South African Road Federation (SARF). The Department of Logistics, University of Stellenbosch, thanks them for the support.

\section{Data availability statement}

Data sharing is not applicable to this article as no new data were created or analysed in this study.

\section{Disclaimer}

The views and opinions expressed in this article are those of the authors and do not necessarily reflect the official policy or position of any affiliated agency of the authors or the funder.

\section{References}

Arrivealive, 2016, 2003 Traffic offence survey: Comprehensive report on fatal crash statistics and road traffic information, viewed 30 November 2016, from https:// www.arrivealive.co.za/2003-TRAFFIC-OFFENCE-SURVEY-Comprehensive-Reporton-Fatal-Crash-Statistics-and-Road-Traffic-Information-11.

Bakwena, 2016, Toll tariffs, viewed 01 June 2016, from https://www.bakwena.co.za/ toll-tariffs/.

Bousquet, F. \& Queiroz, C., 1996, 'Road financing systems: A cross-country comparison of typical issues and good practices', in Proceedings of Seminar G, Volume P406, PTRC, Brunel University, England, September 2-6, 1996, pp. 1-11.

Department of Energy, 2013, Fuel price margins, viewed 02 June 2016, from http://www.energy.gov.za/files/esources/petroleum/petroleum_fuelprices. html.

Department of Logistics, 2017, Funding for roads in South Africa: Understanding the principles of fair and efficient road user charges, Working paper, Stellenbosch University, South Africa.

Department of Transport \& Public Works, 2011, Provincial land transport framework (2011/12-2015/16), Western Cape Provincial Government, Cape Town, South Africa.

Department of Transport, 2013, National transport master plan, National Department of Transport, Pretoria, South Africa.

Department of Transport, 2014, Road infrastructure policy for South Africa: Policy framework: Draft 1, Department of Transport, Pretoria, South Africa.

Department of Transport, 2016, Roads policy for South Africa: Volume 1: Lietrature review and situation analysis report, Department of Transport, Pretoria, South Africa.

Department of Transport, 2017, Draft revised white paper on National Transport Policy, Department of Transport, Pretoria, South Africa.

Department of Transport, 2018a, Draft roads policy for South Africa, Government Gazette No. 41488, 09 March 2018, Department of Transport, Pretoria, South Africa.

Department of Transport, 2018b, Economic regulation of transportation bill, Government Gazette No. 41992, 24 October 2018, Department of Transport, Pretoria, South Africa.

Dutzik, T. \& Weissman, G., 2015, Who pays for roads? How the 'users pay' myth gets in the way of solving America's transportation problems, US PIRG Education Fund, Washington, DC.

eNatis, 2015, Vehicle population statistics, viewed 02 June 2016, from http://www. enatis.com/index.php/statistics/71-live-vehicle-population-per-registeringauthority.

Floor, B.C., 1985, Die geskiedenis van nasionale paaie in Suid Africa, CTP Boekdrukkers, Pretoria.

Freeman, P., 1982, 'The recovery of costs from road users in South Africa', PhD thesis, University of South Africa, South Africa.

Gomez, J. \& Vassallo, J., 2014, 'Comparative analysis of road financing approaches in Europe and the United States', Journal of Infrastructure Systems 20(3), 1-8. https://doi.org/10.1061/(ASCE)IS.1943-555X.0000193 
International Transport Forum, 2015, Transport infrastructure investment and maintenance spending, OECD, viewed 25 August 2016, from https://stats.oecd. maintenance spending, OECD, viewed 25 August
org/Index.aspx?DataSetCode=ITF_INV-MTN_DATA

Julies, A., 2014, The user-pay principle: It's policy, SANRAL, viewed 15 October 2015 from https://stop-over.co.za/the-user-pay-principle-its-policy/.

Kannemeyer, L., 2011, 'RSA road conditions', Presentation: SANRAL, South Africa, March 15, 2011, pp. 1-26.

Kannemeyer, L., 2013, 'Asset management: General status overview', Presentation: SANRAL, South Africa, pp. 1-14.

Kannemeyer, L., 2014, 'South Africa's current road backlogs', Presentation: SANRAL, South Africa, September 02, 2014, pp. 1-26.

Korzhenevych, A., Dehnen, N., Brocker, J., Holtkamp, M., Meier, H., Gibson, G. et al. 2014, Update of the handbook on external costs of transport, European Commission: DG MOVE, London.

Lakshmanan, T.R., 2011, 'The broader economic consequences of transport infrastructure investments', Journal of Transport Geography 19(1), 1-12. https:// doi.org/10.1016/j.jtrangeo.2010.01.001

Metschies, G., 2013, International fuel prices 2012/2013, Deutsche Gesellschaft fur Technische Zusammenarbeit (GTZ), Eschborn.

N3TC, 2016, Toll tariffs, viewed 01 June 2016, from http://www.n3tc.co.za/toll-tariffs/.

National Planning Commission, 2009, National development plan 2030: Our future Make it work: Executive summary, Department: The Presidency, Pretoria, South Africa.

National Surface Transportation Infrasructure Financing Commission, 2009, Paying our way: A new framework for transportation finance, U.S. Department of Transportation, Washington, DC.

National Treasury, 2014a, National assembly question for written reply: Question number 236 (NW285E), National Treasury, Pretoria, South Africa.

National Treasury, 2014b, National budget, National Treasury, Pretoria, South Africa.

National Treasury, 2014c, National budget income 2014, National Treasury, Pretoria, South Africa.

National Treasury, 2014d, Provincial budget, National Treasury, Pretoria, South Africa.

National Treasury, 2015, Provincial budgets and expenditure review 2010/11 2016/17, South Africa, National Treasury, Pretoria, South Africa.

OECD, 2014, Energy prices and taxes: Quarterly statistics, viewed 02 August 2016 from https://www.oecd-ilibrary.org/energy/energy-prices-and-taxes_16096835.

Republic of South Africa, 1996, The constitution of the Republic of South Africa. Act 108 of 1996, Government Printers, Pretoria.

Republic of South Africa, 2000, No 22 of 2000: National Land Transport Transition Act 2000, Government Gazette No. 21493, 23 August 2000, Pretoria, South Africa.

Republic of South Africa, 2009, No 5 of 2009:National Land Transport Act, 2009, Government Gazette No. 32110, 08 April 2009, Pretoria, South Africa.
Republic of South Africa, 2012, Division of Revenue Bill, 2012, National Treasury, Pretoria, South Africa.

Republic of South Africa, 2015a, Appropriation Bill, 2015, National Treasury, Pretoria, South Africa.

Republic of South Africa, 2015b, National Land Transport Strategic Framework, 2015 Government Gazette No. 40621, 17 February 2017, Pretoria, South Africa.

Road Accident Fund, 2014, RAF annual report 2014, Road Accident Fund, Pretoria, South Africa.

Road Traffic Management Corporation, 2014, SA vehicle population, Road Traffic Management Corporation, South Africa, Road Traffic Management Corporation, Pretoria, South Africa.

SANRAL, 2015, The South African National Roads Agency Annual Report 2015, SANRAL, Pretoria, South Africa.

SANRAL, 2016, Toll tariffs, viewed 01 June 2016, from https://www.nra.co.za/live/ content.php?ltem_ID=202.

SAPIA, 2014, SAPIA annual report 2014, SAPIA, NOVA Communications, Pretoria, South Africa.

Stander, H.J. \& Pienaar, W.J., 2000, 'Do South African road users receive a fair deal?', in CSIR International Convention Centre, Pretoria, SA (ed.) 19th South African Transport Conference: Action in Transport for the New Millennium, July 17-20, 2000.

Statistics South Africa, 2014, Statistical release motor trade sales. Pretoria, StatsSa, Pretoria, South Africa.

Statistics South Africa, 2016, Gross domestic product first quarter 2016, StatsSa, Pretoria, South Africa.

Terril, M., Emslie, O. \& Coates, B., 2016, Roads to riches: Better transport investment (No. 2016-5), Grattan Institute, Carlton, Australia.

Trans African Concession, 2016, Toll tariffs, viewed 01 June 2016, from http://www. tracn4.co.za/toll-plazas-toll-fees/.

Transport for Cape Town, 2013, 2013-2018 Comprehensive integrated transport plan Western Cape Provincial Government, Cape Town.

Van Lingen, A., 1960, n Eeu van vervoer 1860-1960: die prestasies van die Ministerie van Vervoer van die Unie van Suid-Africa, Da Gama, Johannesburg, South Africa.

Van Rensburg, J. \& Krygsman, S., 2015, 'Running dry: Assessing the fuel levy as a long term economically efficient road use fund', in 34th Annual South African Transport Conference - Transport: Working together to deliver, CSIR Internationa Convention Centre, Pretoria, South Africa, July 6-9, 2015, pp. 596-610.

Van Rensburg, J. \& Krygsman, S., 2019, 'Disruptive transport technologies: Impact on road generated revenues', in 38th Annual South African Transport ConferenceTransport: Disruptive transport technologies - Is South and Southern Africa ready? CSIR International Convention Centre, Pretoria, South Africa, July 8-11, 2019, pp. 1-12.

Whitty, J. \& Imholt, B., 2007, Oregon's mileage fee concept and road user fee pilot program, Oregon Department of Transportation, Salem, OR. 